\title{
Factors affecting the results of comprehensive pre-internship exam among medical students of Kermanshah University of Medical Sciences
}

\author{
Mohammad Rasool Khazaei, Afshin Zarin, Mansuor Rezaei and Mozafar Khazaei \\ Fertility and Infertility Research Center, Kermanshah University of Medical Sciences, Kermanshah, Iran
}

Purpose: This study was aimed to evaluate the factors affecting the results of comprehensive pre-internship exam (CPIE) among medicals students of Kermanshah University of Medical Sciences.

Methods: In this descriptive-analytical study, all students ( $n=240)$ participating in CPIE over a 3-year period (2012-2014) were selected. Data were gathered by a questionnaire, including the CPIE results and educational and demographic data. Spearman correlation coefficient, Mann-Whitney U-test, and analysis of variance were used to analyze the association of students' success with study variables. Also, regression analysis was applied to determine the role of independent variables in students' success. Results: The frequency of the failed units in apprenticeship course was one of the most important risk factors associated with failure in CPIE. Average scores of pre-internship course were the most important factors of success in CPIE. The CPIE score had the highest direct relationship with grade point average (GPA) of apprenticeship course, total GPA of all three courses, GPAs of physiopathology and basic sciences courses, and score of comprehensive basic sciences examination, respectively.

Conclusion: CPIE showed the highest inverse correlation with the number of failed units in apprenticeship course. The most important factors influencing this exam were failure in apprenticeship course and GPA of previous educational stages.

Key Words: Internship and residency, Medical education, Medical students, Kermanshah

\section{Introduction}

General medicine program in Iran takes 7 years to complete. It consists of four levels, including basic sciences (5 semesters), physiopathology (2 semesters), apprenticeship (4 semesters) and internship (3 semesters). Each student, in addition to the regular final term examinations, has to take two comprehensive examinations, including basic sciences (comprehensive basic sciences examination, CBSE) and pre-internship (comprehensive pre-internship exam, CPIE), which are prerequisite to admission to the following stages. An educational program is successful and efficient when a correct assessment is carried out in it. At the end of each educational level, it is necessary to evaluate its success and to determine the factors needed to create changes compatible with educational needs. Identification of the weaknesses and strengths of educational programs is an important responsibility of educational planners, which
Received: November 17, 2017 • Revised: January 23, 2018 • Accepted: March 4, 2018 Corresponding Author: Mozafar Khazaei (https://orcid.org/0000-0003-0536-3217) Fertility and Infertility Research Center, Kermanshah University of Medical Sciences, Shahid Shiroudi Blvd, University Ave, Kermanshah, Iran

Tel: +98.83.34274618 Fax: +98.83.34281563 email: mkhazaei1345@yahoo.com
Korean J Med Educ 2018 Jun; 30(2): 131-139.

https://doi.org/10.3946/kjme.2018.88

eISSN: 2005-7288

(C) The Korean Society of Medical Education. All rights reserved. This is an open-access article distributed under the terms of the Creative Commons Attribution Non-Commercial License (http:// creativecommons.org/licenses/by-nc/3.0/), which permits unrestricted non-commercial use, distribution, and reproduction in any medium, provided the original work is properly cited. 
is carried out through a systematic data collection process and analysis and interpretation of data to achieve the predicted objectives [1,2].

Among the ongoing stages of general medicine education, apprenticeship course can be called the most important and critical stage in which the students move from theoretical stage to practical stage and see themselves acting as a physician [3]. Williams et al. [4] evaluated the articles published on outpatient education from 2001 to 2011 and recommended establishing systems to both support education and research simultaneously at medical faculties and provide a suitable ground for the required changes. Regular assessment of the curricula and analysis of students' educational status in different levels are the essential and inevitable foundations for improving the quality of educational programs at universities so that any change in educational planning and performance requires assessment of the existing condition and receiving the relevant feedback [5,6].

The quality of medical education is promoted by monitoring and identifying the weaknesses and strengths of the program. Students' assessment in various levels of education has always been considered by the medical education authorities. It seems that CPIE is the most significant examination for medical students, which is administered at the end of the apprenticeship program and analyzes the theoretical capabilities of students [2,7]. The conditions for taking this test are passing all courses and apprenticeship stages with a minimum score of 12 and minimum grade point average (GPA) of 14 as well as registering the subject of thesis. This examination is run as multiple choice and administered twice a year in September and March, which is a prerequisite to internship program.

Many interns regard CPIE necessary for assessing their theoretical and practical knowledge. Some students believe that it is better to use half of this examination score for students' assessment, although some others have reported this examination to be inappropriate for assessing the students' skills and attitude [8,9]. Since the results of this examination are used as a criterion for medical students' academic achievement, acceptance in it is of great significance for the students and medical universities, and one of the criteria used to determine the education level of universities is the ranking obtained by each medical faculty in this examination. Further, problems such as inability in passing the following academic levels, delay in graduation, deprivation from schooling, loss of time, financial losses, and reduced scientific level of university are the consequences of failure or poor results in this examination $[1,2,10]$.

As for success or failure in CPIE, numerous studies have been published and various factors have been reported to affect its results. For example, the success rate in Kashan School of Medicine was found to be 90.8\% [3] and that of Baqiyatallah School of Medicine was reported to be $79.32 \%$ [11]. Also, the GPA of basic sciences course was the most important factor affecting failure in CPIE [3]. A study showed 62\% relationship between the mean total score of students and score changes of pre-internship examination [10]. Further, the failure rates of medical students in CPIE in September and March 2001 at Zahedan University of Medical Sciences were $26 \%$ and $16 \%$, respectively [7]. The results of linear regression analysis in a study in Kerman University of Medical Sciences indicated that increasing each unit in the average score of clinical grade mean score, CBSE score and the average of the physiopathology course, and the pre-internship exam score increased by $0.46,0.36$, and 0.25 units, respectively. In this university, gender was introduced as a predictor of CPIE score [12]. 
With regard to the students' success or failure in medicine program, factors such as diploma GPA and GPAs of basic sciences, physiopathology and apprenticeship, score of CPIE and CBSE, history of being on probation, quota for admission, gender, duration of education, student's employment, and being native $[1,2,13]$ have been proposed and investigated, the results of which are contradictory in some cases. These differences are indicative of the necessity of evaluating the above-mentioned factors in various universities. Thus, given the significance of CPIE at the beginning of internship program and the need for analyzing the influential factors involved in it, the current study was carried out to determine the factors affecting the results of CPIE in medical students at Kermanshah University of Medical Sciences.

\section{Methods}

In this descriptive-analytical study, all medical students of Kermanshah University of Medical Sciences who participated in CPIE during 2012-2014 (a 3-year period) and satisfied all the study criteria were selected. Students who were transferred to or were guests from other universities were excluded from the study. Finally, 240 students were chosen, whose data were obtained from the documents in education departments of university and faculty using the forms, including demographic data (gender, residence, and quota) and educational data (CBSE score, CPIE score, and GPAs of basic sciences, physiopathology and apprenticeship courses). This study was approved by the Institutional Review Board of Kermanshah University of Medical Sciences (IRB approval no., 93509). To keep the data confidential, a specific code was allocated to each form. It should be noted that before administration of the forms, their face validity was confirmed by four faculty members experienced in education. Iranian university used a unique throughout entrance exam named Konkor, which organized by a national organization. In this exam, students get a quota code (1, 2, 3, and particular) according to quality of their high school education and some socioeconomic criteria. The code one means higher quality of education and particular quota needs special care.

The frequency of failure was calculated by software (SPSS ver. 16.0; SPSS Inc., Chicago, USA). KolmogorovSmirnov test was used to determine the normality of distribution of variables. Spearman correlation coefficient was used to analyze the correlation of students' success with quantitative variables. Further, MannWhitney test was used to determine the association of students' success with bivariate variables like gender and one-way analysis of variance test was applied to evaluate the multivariate variables. In the end, logistic regression analysis was run to determine the effect of independent variables on the frequency of students' success, taking into account the effect of confounding factors.

\section{Results}

In this study, from 240 participants, 55.8\% were female, $53.3 \%$ lived in the dormitory and $45 \%$ had quota two for university entrance examination (Table 1). The mean scores of CBSE and CPIE were 124.04 and 118.67, respectively. The mean numbers of units passed in basic sciences, physiopathology, and apprenticeship courses were 100.6, 29.7, and 102.1, respectively, and the mean GPAs of these three courses were 14.4, 14.4, and 15.9, respectively (Table 2). In all three courses, 45 students (18.5\%) had a GPA $<14$ and $>12$ and 14 students (5.8\%) of them had a GPA $>17$, and the mean of GPA of these 
Table 1. Demographic Information of the Students Participating in Comprehensive Pre-internship Exam

\begin{tabular}{lc}
\hline \multicolumn{1}{c}{ Characteristic } & No. $(\%)$ \\
\hline Gender & \\
Male & $106(44.2)$ \\
Female & $134(55.8)$ \\
Residence & \\
Dormitory & $128(53.3)$ \\
Non-dormitory & $96(40.0)$ \\
Uncertain & $16(6.7)$ \\
Quota (for university entrance examination) & \\
Region 1 & $14(5.8)$ \\
Region 2 & $108(45.0)$ \\
Region 3 & $75(31.2)$ \\
Particular & $43(17.9)$ \\
\hline
\end{tabular}

three courses being found to be 15.04.

Other characteristic on failed units, GPA, and educational result of three study periods (basic science, physiopathology, and apprenticeship) were showed in Table 3. The highest failed unit was seen in basic science course and the worst result was in CPIE. The score of CPIE had the highest direct correlation with GPA of apprenticeship course, mean GPA of three courses, GPA of physiopathology, GPA of basic sciences, and score of CBSE. It also had the highest inverse correlation with the number of failed units in apprenticeship course (Table 4).

Table 2. Total Mean of the Units Taken, Failed, and Passed, and Students' GPA in Basic Sciences, Physiopathology, and Pre-interns
\begin{tabular}{lccc} 
Courses \\
\multicolumn{1}{c}{ Variable } & Basic sciences & Physiopathology & Pre-internship \\
\hline Mean no. of units taken & 100.60 & 29.70 & 102.10 \\
Mean no. of units failed & 4.60 & 0.93 & 2.10 \\
Mean no. of units passed & 96.00 & 28.77 & 100.00 \\
Mean GPA of the course & 14.40 & 14.41 & 15.90 \\
Mean of comprehensive pre-internship exam scores & 124.00 & - & 118.70 \\
\hline
\end{tabular}

GPA: Grade point average.

\begin{tabular}{ccccccc}
\hline Table 3. Characteristics of Courses, GPA, and Comprehensive Examinations & & & & \\
\hline Variable & $\begin{array}{c}\text { Without failed unit } \\
\text { student }\end{array}$ & $\begin{array}{c}\text { Most failed unit } \\
\text { student }\end{array}$ & Unsuitable GPA & $\begin{array}{c}\text { Excellent GPA } \\
(\geq 17)\end{array}$ & $\begin{array}{c}\text { Unsuitable score } \\
\text { of comprehensive } \\
\text { examinations } \\
(<100)\end{array}$ & $\begin{array}{c}\text { Suitable score } \\
\text { of comprehensive } \\
\text { examinations } \\
(>150)\end{array}$ \\
\hline $\begin{array}{c}\text { Basic science } \\
\text { course }\end{array}$ & $123(51.0)$ & $2(0.9)(50$ units) & $4(1.7)(<12)$ & $12(5.0)$ & $19(8.6)$ & $18(7.7)$ \\
$\begin{array}{c}\text { Physiopathology } \\
\text { course }\end{array}$ & $196(87.7)$ & $4(1.7)(14$ units) & $6(2.5)(<12)$ & $10(4.2)$ & - & - \\
$\begin{array}{c}\text { Apprenticeship } \\
\text { course }\end{array}$ & $170(70.8)$ & $4(1.7)(>20$ units) & $4(1.7)(<14)$ & $28(11.6)$ & $46(19.1)$ & $18(7.7)$ \\
\hline
\end{tabular}

Data are presented as number $(\%)$.

GPA: Grade point average.

\begin{tabular}{|c|c|c|c|c|c|c|c|}
\hline $\begin{array}{c}\text { Pearson } \\
\text { correlation Sig } \\
\text { (2-tailed) } \\
\end{array}$ & $\begin{array}{l}\text { GPA of basic } \\
\text { sciences }\end{array}$ & $\begin{array}{c}\text { GPA of } \\
\text { physiopathology }\end{array}$ & $\begin{array}{c}\text { GPA of } \\
\text { apprenticeship }\end{array}$ & $\begin{array}{l}\text { Total GPA of } \\
\text { three courses }\end{array}$ & CBSE score & $\begin{array}{c}\text { Failed units of } \\
\text { basic sciences } \\
\text { course }\end{array}$ & $\begin{array}{l}\text { Failed units of } \\
\text { apprenticeship } \\
\text { course }\end{array}$ \\
\hline CPIE score & $0.34^{\mathrm{al}}$ & $0.42^{\mathrm{al}}$ & $0.52^{\mathrm{al}}$ & $0.37^{a \mid}$ & $-0.32^{\text {al }}$ & $-0.21^{b l}$ & $-0.30^{\mathrm{al}}$ \\
\hline CBSE score & $0.75^{\mathrm{al}}$ & $0.67^{\mathrm{al}}$ & $0.59^{\mathrm{al}}$ & $-0.73^{\mathrm{al}}$ & $1^{a \mid}$ & $-0.40^{\mathrm{al}}$ & $-0.33^{\mathrm{al}}$ \\
\hline
\end{tabular}

CPIE: Comprehensive pre-internship exam, CBSE: Comprehensive basic sciences examination, GPA: Grade point average.

${ }^{\text {a) }} p=0.001,{ }^{\text {b) }} p=0.002$. 


\begin{tabular}{|c|c|c|c|c|c|c|c|c|c|}
\hline Variable & Sex & $\mathrm{p}$-value & $\begin{array}{c}\text { Mean } \\
\text { rank }\end{array}$ & Live in & $\begin{array}{l}\text { Asymp. Sig } \\
\text { (2-tailed) }\end{array}$ & $\begin{array}{c}\text { Mean } \\
\text { rank }\end{array}$ & Locale & $\begin{array}{l}\text { Asymp. Sig } \\
\text { (2-tailed) }\end{array}$ & $\begin{array}{l}\text { Mean } \\
\text { rank }\end{array}$ \\
\hline $\begin{array}{l}\text { Average of basic } \\
\text { sciences }\end{array}$ & $\begin{array}{l}\text { Male } \\
\text { Female }\end{array}$ & 0.000 & $\begin{array}{r}99.84 \\
136.84\end{array}$ & $\begin{array}{l}\text { No dormitory } \\
\text { Dormitory }\end{array}$ & 0.010 & $\begin{array}{l}102.88 \\
125.33\end{array}$ & $\begin{array}{l}1 \\
2 \\
3 \\
\text { Particular }\end{array}$ & 0.001 & $\begin{array}{r}99.64 \\
115.76 \\
107.10 \\
64.42\end{array}$ \\
\hline $\begin{array}{l}\text { Averageof } \\
\text { physiopathology }\end{array}$ & $\begin{array}{l}\text { Male } \\
\text { Female }\end{array}$ & 0.000 & $\begin{array}{l}102.50 \\
134.74\end{array}$ & $\begin{array}{l}\text { No dormitory } \\
\text { Dormitory }\end{array}$ & 0.026 & $\begin{array}{l}104.16 \\
123.61\end{array}$ & $\begin{array}{l}1 \\
2 \\
3 \\
\text { Particular }\end{array}$ & 0.064 & $\begin{array}{r}118.79 \\
103.19 \\
97.54 \\
117.89\end{array}$ \\
\hline Average of internship & $\begin{array}{l}\text { Male } \\
\text { Female }\end{array}$ & 0.000 & $\begin{array}{r}95.79 \\
140.04\end{array}$ & $\begin{array}{l}\text { No dormitory } \\
\text { Dormitory }\end{array}$ & 0.047 & $\begin{array}{l}105.05 \\
122.44\end{array}$ & $\begin{array}{l}1 \\
2 \\
3 \\
\text { Particular }\end{array}$ & 0.017 & $\begin{array}{r}106.86 \\
111.56 \\
109.79 \\
73.83\end{array}$ \\
\hline $\begin{array}{l}\text { Comprehensive basic } \\
\text { science graduate } \\
\text { score }\end{array}$ & $\begin{array}{l}\text { Male } \\
\text { Female }\end{array}$ & 0.555 & $\begin{array}{l}107.50 \\
112.70\end{array}$ & $\begin{array}{l}\text { No dormitory } \\
\text { Dormitory }\end{array}$ & 0.008 & $\begin{array}{r}96.09 \\
118.81\end{array}$ & $\begin{array}{l}1 \\
2 \\
3 \\
\text { Particular }\end{array}$ & 0.108 & $\begin{array}{r}82.73 \\
104.45 \\
100.24 \\
77.45\end{array}$ \\
\hline $\begin{array}{l}\text { Comprehensive } \\
\text { pre-internship } \\
\text { graduate score }\end{array}$ & $\begin{array}{l}\text { Male } \\
\text { Female }\end{array}$ & 0.240 & $\begin{array}{l}123.89 \\
113.40\end{array}$ & $\begin{array}{l}\text { No dormitory } \\
\text { Dormitory }\end{array}$ & 0.284 & $\begin{array}{l}113.96 \\
104.73\end{array}$ & $\begin{array}{l}1 \\
2 \\
3 \\
\text { Particular }\end{array}$ & 0.005 & $\begin{array}{r}95.15 \\
103.20 \\
120.95 \\
73.77\end{array}$ \\
\hline $\begin{array}{l}\text { Total grade for all three } \\
\text { courses }\end{array}$ & $\begin{array}{l}\text { Male } \\
\text { Female }\end{array}$ & 0.000 & $\begin{array}{r}96.73 \\
139.30\end{array}$ & $\begin{array}{l}\text { No dormitory } \\
\text { Dormitory }\end{array}$ & 0.009 & $\begin{array}{l}102.72 \\
125.54\end{array}$ & $\begin{array}{l}1 \\
2 \\
3 \\
\text { Particular }\end{array}$ & 0.002 & $\begin{array}{r}101.64 \\
114.86 \\
107.72 \\
68.52\end{array}$ \\
\hline
\end{tabular}

Asymp. Sig: Asymptotic significance.

There was a significant difference between gender and GPA of basic sciences, GPA of physiopathology, GPA of apprenticeship, and total GPA of the three courses. In all four cases, the females had a significantly better performance than males $(\mathrm{p}=0.000)$, but gender had no effect on the scores of CBSE and CPIE (Table 5). The GPAs of basic sciences, physiopathology, and apprenticeship courses, the mean GPA of these three courses, and the score of CBSE were found to be significantly different between the dormitory students and nondormitory ones; the performance of non-dormitory students being better than the dormitory students. It should be noted that despite the significant difference $(\mathrm{p}=0.000)$ between the dormitory and non-dormitory students in CBSE, no significant difference was found for CPIE.
Regarding the quota for university entrance examination, there was a significant difference among the regions one, two, and three and particular quotas (non-regional), GPA of basic sciences course, GPA of apprenticeship course, and GPA of all three courses (basic sciences, physiopathology, and apprenticeship) $(\mathrm{p}=0.000)$. In all three cases, the best performance was reported for the students with regions two and three quotas and the worst performance was found for students with particular quota, although this difference was not significant for GPA of physiopathology course. In addition, the score of CPIE was significantly different between the regions of university entrance examination $(p=0.001)$, the best performance being reported for the students with region three quota, and the worst performance for particular students. Based on stepwise 


\begin{tabular}{|c|c|c|c|c|}
\hline \multirow{2}{*}{ Dependent variable } & \multirow{2}{*}{ Model } & \multicolumn{2}{|c|}{ Coefficients } & \multirow{2}{*}{ p-value } \\
\hline & & $\mathrm{B}$ & Standard error & \\
\hline \multirow[t]{3}{*}{ Comprehensive pre-internship exam score } & (Constant) & -363.046 & 46.627 & 0.000 \\
\hline & Average of internship & 10.428 & 1.477 & 0.000 \\
\hline & CBSE score & 0.222 & 0.080 & 0.006 \\
\hline \multirow[t]{3}{*}{ CBSE score } & (Constant) & -8.480 & 34.718 & 0.807 \\
\hline & Average of basic sciences & 8.163 & 1.066 & 0.000 \\
\hline & Average of physiopathology & 3.010 & 0.923 & 0.001 \\
\hline
\end{tabular}

CBSE: Comprehensive basic sciences examination.

method, in the case of controlling the confounding effect, the GPA of apprenticeship course and score of CBSE had the highest correlation with score of CPIE (Table 6).

\section{Discussion}

In this study, the score of CPIE had the highest correlation with GPA of apprenticeship course, mean GPA of all three courses, GPA of physiopathology, GPA of basic sciences, and score of CBSE, respectively. The CPIE had the highest inverse correlation with the number of failed units in apprenticeship course, and the most important factor involved in failing the preinternship tests was the number of failed units in apprenticeship course. From 240 students, 134 students (55.8\%) were female. Since the quota of university entrance examination for medicine allocated to both men and women is $40 \%$, and there is a competition between them only in the remaining $20 \%$, this study showed that $75 \%$ of the competitive quota $(20 \%)$, i.e., 3 times more, was allocated to females. This superiority of females can be due to absence of compulsory military service for females and their higher chance for participation in university entrance examination, or higher tendency of native female candidates with higher ranking for studying and staying in their hometowns.
In the present study unlike the results of some former studies $[2,7,11,14]$, gender did not have a significant effect on the result of CPIE. On the other hand, gender had a significant relationship with GPAs of basic sciences, physiopathology, and apprenticeship and total GPA of these three courses, and females performed better than males in all four domains, which is in line with some domestic studies $[1,14,15]$ and results of Dublin University in Ireland, indicating that women had a significantly better performance in the final examinations of medicine [13]. Mills et al. [16] also proposed gender as a predictor of academic achievement. Factors such as concern about employment, employment after graduation, and low motivation have been reported to cause poor academic performance in men [17-20]. However, the larger number of male students in particular quota can also be due to their poor educational performance. Thus, some researchers have emphasized the necessity of more accurate analysis of the effect of gender on students' academic performance in examinations [21].

Since the GPAs of basic sciences, physiopathology, and apprenticeship courses were higher in nondormitory students than in dormitory students, the role of family support in students' success can be considered a significant factor because most of the dormitory students face more problems than non-dormitory problems during their schooling, including lack of 
emotional support by the family, improper nutrition, and commuting. Despite the significantly better performance of non-dormitory students than dormitory students in CBSE in this study, which was in line with some other studies [1,13], no significant difference was found between dormitory and non-dormitory students in CPIE. This can be associated with the fact that with the passage of time, dormitory students adapt more to the dormitory conditions and academic education and approach non-dormitory students in performance on courses.

In this study, CPIE had the highest correlation with GPA of apprenticeship course, which is in agreement with the results of previous studies $[2,9,14,19]$. Since success in CPIE is more correlated to the GPA of apprenticeship rather than GPA of basic sciences, it can be concluded that this significant difference is because of more closeness of apprenticeship courses with medical profession and CPIE rather than basic sciences courses in terms of content and practicality.

The current study, the same as former studies $[2,11,14,19]$, confirmed the effect of GPA of basic sciences on the result of CPIE. Also, in Zahedan University of Medical Sciences, a significant correlation (>0.7) was observed between the GPA of basic sciences and score of apprenticeship examination [9]. Further, the present study showed the GPAs of both basic sciences and apprenticeship courses had the highest correlation with CPIE and CBSE that is the mean performance of the previous 2 years of students is a strong predictor of their success in each of these comprehensive examinations.

In the current research, the significant effect of the GPA of physiopathology on the result of CPIE confirmed the results of several other studies $[2,10,14,20]$. The poorest performance in this study was reported for the score of CPIE, GPA of basic sciences course, and GPA of all three courses (basic sciences, physio- pathology, and apprenticeship) among students with particular quota, which is similar to the findings of previous studies $[7,10,22]$. Therefore, the problems of students admitted to university using special quotas should not be ignored.

As for the role of each of the studied factors and the reasons explained for the differences between various studies, it is noteworthy that factors such as time, place, and sampling method need to be taken into account. Moreover, this study was conducted based on the data in students' files, and due to this limitation, it was not possible to consider many personal and environmental factors. Thus, it is necessary to perform an accurate analysis of students in CPIE in each course among various universities. Furthermore, there may be no cause-effect relationship between the score of CPIE and some studied factors, and these factors may have been affected by some other factors like IQ (intelligence quotient) and motivation. Conducting experimental studies in this regard can help educational authorities to present more effective programs in order to prevent failure in CPIE. Studies showed that changing the teaching method of basic sciences courses and students' participation in the teaching process had a positive impact on the learning and understanding of all students with regional and no-regional quotas [23,24]. To increase the success and to prevent the consequences of failure in CPIE, it is necessary to identify the students at risk and to design appropriate educational and supplementary programs.

In conclusion, the most important factor involved in failure in CPIE was the number of failed units in apprenticeship course and the most significant factors involved in success in CPIE were GPA of apprenticeship and score of CBSE. Gender and being a dormitory or non-dormitory student had no significant effect on the score of CPIE. Moreover, the score of CPIE was 
significantly correlated to different quotas of university entrance examination.

\section{ORCID:}

Mohammad Rasool Khazaei: https://orcid.org/0000-0001-9818-0625; Afshin Zarin: https://orcid.org/0000-0003-2993-1354;

Mansuor Rezaei: https://orcid.org/0000-0002-6446-7289;

Mozafar Khazaei: https://orcid.org/0000-0003-0536-3217

Acknowledgements: This article was taken from a general medicine thesis (registration no., 93509). The authors appreciate the cooperation of deputy of education of Kermanshah University of Medical Sciences and all education experts, especially Ms. Ghanbari in data collection process.

Funding: None.

Conflicts of interest: No potential conflict of interest relevant to this article was reported.

Author contributions: Conception and design of the work: MRK, AZ, MK, MR; data collection and carrying out the experiment: MRK, AZ, MK, MR; drafting the article: MRK, AZ, MK, MR; writing parts of the manuscript and acting as corresponding author: MK; and overall supervision, drafting and statistical analysis, interpretation of data, editing, and approving the final version of this paper for submission and collaboration in the preparation/revision of the submitted manuscript: MRK, MK.

\section{References}

1. Avizhgan M, Farzanfar E, Najafi MR, Shams B, Ashoorion V. Ambulatory education quality in Al-Zahra Hospital Clinics in Isfahan: view of clerkships students and interns. Iran J Med Educ. 2011;10(5):896-905.

2. Khazaei M, Rezaei M, Khazaei S. Survey of personal and educational characters in unsuccess medical students in compare with success students. Koomesh. 2008;9(2): 87-92.

3. Fakharian E, Tagharrobi Z, Mirhoseini F, Rasoulinejad SA, Akbari H, Ameli H. Influential factors on results of comprehensive pre-internship exam in medical faculty of Kashan University of Medical Sciences: survey of an 18-year period. Hakim Res J. 2012;15(3):203-212.

4. Williams CK, Hui Y, Borschel D, Carnahan H. A scoping review of undergraduate ambulatory care education. Med Teach. 2013;35(6):444-453.

5. Eleazer GP, Stewart TJ, Wieland GD, Anderson MB, Simpson D; Steering Committee of the National Evaluation of Senior Mentor Programs. The national evaluation of senior mentor programs: older adults in medical education. J Am Geriatr Soc. 2009;57(2):321-326.

6. Khazaei M, Abasi F, Khazaei MR, Rahimi F. Educational status of dental basic science course and its correlation with students' educational background in Kermanshah University of Medical Sciences. Educ Res Med Sci. 2014;2(3):10-16.

7. Roudbari M, Sheibak A. The survey of the result and the associated factors in the pre internship examination at Zahedan University of Medical Sciences in September \& Mars 2001. Zahedan J Res Med Sci. 2006;8(1):19-27.

8. Nazem M, Garakyaraghi M, Hosseinpour M. Interns' viewpoints concerning their readiness for entering internship in Isfahan Medical University. Iran J Med Educ. 2005;5(2):157-164.

9. Nasri K, Kahbazi M, Nasri S. Medical students' viewpoints toward basic sciences and preinternship comprehensive exams in Arak University of Medical Sciences. Iran J Med Educ. 2010;10(1):82-91.

10. Roudbari M, Movahed S. The related factors on the pre-internship scores and the exam result of Zahedan medical students in 2000. Strides Dev Med Educ. 2005;1(2):94-103. 
11. Rahmani R, Mehrvarz Sh, Hosseini Aghdam SK, Hashemi S. Pre-internship comprehensive test status in medical students and its related factor. Educ Strateg Med Sci. 2012;5(1):39-43.

12. Haghdoost AA, Esmaeili A. The correlation between medical students' scores in their physiopathology and clinical courses in Kerman University of Medical Sciences. J Med Educ. 2006;10(1):11-17.

13. McDonough CM, Horgan A, Codd MB, Casey PR. Gender differences in the results of the final medical examination at University College Dublin. Med Educ. 2000;34(1):30-34.

14. Haghdoost AA, Esmaeili A. Educational achievement in medical students entered university between 1995 and 2003, Kerman University of Medical Sciences. Strides Dev Med Educ. 2009;5(2):80-87.

15. Falahzadeh M, Rezaei R. A study of the correlation between some pre-university factors and educational outcome and success of medical students. J Soc Sci Humanit Shiraz Univ. 2005;22(4):205-210.

16. Mills C, Heyworth J, Rosenwax L, Carr S, Rosenberg M. Factors associated with the academic success of first year health science students. Adv Health Sci Educ Theory Pract. 2009; 14(2):205-217.

17. Rashidi-Nejad HR, Mortazavi SM. Increased female/male student ratio and the higher academic achievement of the female students of Rafsanjan University of Medical Sciences in academic year 2003-2004. J Rafsanjan Univ Med Sci. 2005;4(3):180-185.
18. Tamannaaeefar MR, Niazi M, Amini M. Comparative survey of the influencing factors on educational drop-out in probative and successful students. Daneshvar Raftar. 2007; 14(24):39-52.

19. Taheri MM, Ryasi HR, Afshar M, Mofatteh MR. Comparison between student rating, faculty self-rating and evaluation of faculty members by heads of respective academic departments in the school of medicine in Birjand University of Medical Sciences in Iran. J Educ Health Promot. 2014;3:34.

20. Emam GF, Heydari ST, Najafipour S. Evaluation of effecting factors on educational status of medical students in Jahrom Medical University during 19942003. J Babol Univ Med Sci. 2010;12(Suppl 1):40-45.

21. Frischenschlager O, Haidinger G, Mitterauer L. Factors associated with academic success at Vienna Medical School: prospective survey. Croat Med J. 2005;46(1): 58-65.

22. Behboudi F, Panahandeh Z. Predictive validity of the comprehensive basic science examination mean score for assessment of medical students' performance. J Med Educ. 2002;1(3):137-138.

23. Van der Vleuten C. Validity of final examinations in undergraduate medical training. BMJ. 2000;321(7270): 1217-1219.

24. Khazaei M, Khazaei MR, Mohseni GH, Ansarian A. The effect of student group work on the presentation process of general embryology course to medical student. Edu Res Med Sci. 2012;1(2):12-16. 